\begin{tabular}{|c|c|}
\hline \multirow{3}{*}{ 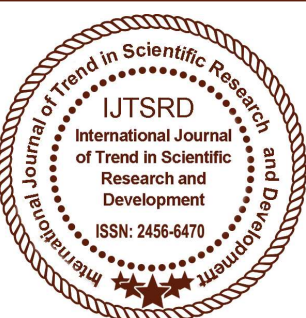 } & $\begin{array}{l}\text { International Journal of Trend in Scientific } \\
\text { Research and Development (IJTSRD) }\end{array}$ \\
\hline & International Open Access Journal \\
\hline & ISSN No: 2456 - 6470 | www.ijtsrd.com | Volume - 2 | Issue - 5 \\
\hline
\end{tabular}

\title{
Experimental Investigation on the Properties of Concrete with Plastic Pet Bottle Fibers as Partial Replacement of Fine Aggregates
}

\author{
Abid Hussain Malik ${ }^{1}$, Mohd Zeeshan Khan ${ }^{2}$, Dr. Asif Hussain ${ }^{3}$ \\ ${ }^{1}$ PG Student, Construction Technology \& Management, Al-Falah University, Haryana, India. \\ ${ }^{2}$ Assistant Professor, Civil Engineering Department, Al-Falah University, Haryana, India. \\ ${ }^{3}$ Professor, Department of Civil Engineering, Jamia Millia Islamia, New Delhi, India.
}

\section{ABSTRACT}

Industrial activities in India are associated with significant amounts of non-biodegradable solid waste, waste plastic being among the most prominent. This study involved 86 experiments and 254 tests to determine the efficiency of reusing waste plastic in the production of concrete. Thirty kilograms of waste plastic of fabriform shapes was used as a partial replacement for sand by $0 \%, 1 \%, 2 \%, 2.5 \%, 3 \%$ and $5 \%$ with $80 \mathrm{~kg}$ of concrete mixtures.

All of the concrete mixtures were tested at room temperature. These tests include performing slump, compressive strength, cost analysis, and weight analysis. 14 cubes were molded for compressive strength and dry density tests, Curing ages of 3, 7, 14, and 28 days for the concrete mixtures were applied in this work. The results proved the arrest of the propagation of micro cracks by introducing waste plastic of fabriform shapes to concrete mixtures. This study insures that reusing waste plastic as a sandsubstitution aggregate in concrete gives a good approach to reduce the cost of materials and solve some of the solid waste problems posed by plastics.

Keywords: Non-Biodegradable, Concrete, PET Bottles, Aggregates.

\subsection{INTRODUCTION}

Concrete is a versatile material for civil engineering construction. It has ability to get cast in any form and shape. All basic ingredients of concrete are natural origin. But the properties of concrete can be change by adding some special natural or artificial ingredients. It has many advantageous properties such as good compressive strength, durability, specific gravity and fire resistance. However, it has some negative properties, like- low tensile strength, brittleness, lower impact strength, less resistance to cracking, heavy weight etc. Still concrete is better option than any other available materials for civil engineering constructions. Some remedial measures can be taken to minimize these negative properties of concrete. Some of the undesirable properties of concrete are due to micro cracks at mortar aggregate interface. Some of these bitter properties can be enhanced by adding fibers with other ingredients of the concrete. The fibers inclusion in concrete acts as unwanted micro crack arrester. In presence of fibers the crack prorogation is delayed which helps in improvement in static and dynamic properties of concrete.

The consumption of plastic has grown substantially all over the world; it leads to create large quantities of plastic-based waste. It is common to serve the mineral water in plastic bottles (Polyethylene Teraphthelne (PET) bottles) in every country. Plastic waste is the one of the challenges to dispose and manage as it is non-biodegradable material which is harmful to our beautiful environment.

Concrete is the most widely used construction material in the world due to its high compressive strength, long service life, and low cost. Nowadays, unfortunately, the recycling rate of PET bottles is much less than the sales of virgin PET production for common uses. This gap is dramatically increasing, pushing towards finding a solution of this problem and a higher recycle of PET. Particular interest is stirring, at present, the use of fibers obtained from 
waste PET bottles. A possible application is to utilize waste PET fibers as replacement of fine aggregates in concrete. The purpose of this project is to evaluate the possibility of using granulated plastic waste materials to partially substitute for the fine aggregate (sand) in concrete composites.

Considerable researches and studies were carried out in some countries like USA and UK on this topic. However, there have been very limited studies in India on plastics in concrete. Hence an attempt on the utilization of waste Poly-ethylene Terephthalate (PET) bottle granules as fine aggregate is done and its mechanical behavior is investigated.

Further research to evaluate the use of plastic waste in concrete production is therefore required. This is the background of our present study. The waste Polyethylene Terephthalate (PET) bottles were converted into fibers and added in concrete as an additional ingredient of concrete. The tensile, flexure and compressive strength of conventional concrete and PET fiber reinforced concrete were determined. The results are then analyzed and compared.

\subsection{OBJECTIVES}

Main Objective

$>$ To investigate the properties of concrete when waste plastics in powdered form is used as partial replacement of fine aggregates in concrete.

\section{Specific Objectives}

$>$ To compare the properties like compressive strength, workability, impermeability and density of conventional concrete with the concrete produced by using plastic wastes.

$>$ To find a means of reducing the pressure on natural resources of earth by decreasing the use of conventional aggregates.

$>$ To compare the physical characteristics including toughness, specific gravity, water absorption capacity etc. of conventional aggregate with aggregate obtained from plastic wastes.

$>$ To produce light weight concrete for multipurpose use.

$>$ To provide a safe and useful method of disposal of harmful non biodegradable plastic wastes.

$>$ To affect economy in concrete production.

$>$ To examine the applicability of my experimental findings in field.

\subsection{METHODOLOGY}

In this project, river sand found in percentages $5 \%$, $10 \%, 15 \% \& 20 \%$ is substituted for 20,25 and 30 molar grade concrete. The amount of replacement percentage with respect to volume wise in comparison to the total volume is relative and it is blend proportioned. $150 \mathrm{~mm} \times 150 \mathrm{~mm} \times 150 \mathrm{~mm}$ cubical and axle specimens of admeasurements $100 \mathrm{~mm} \times$ $100 \mathrm{~mm} \times 500 \mathrm{~mm}$ and the butt specimens' admeasurements are $150 \mathrm{~mm} \times 600 \mathrm{~mm}$ dia of 36 numbers are chosen for the purpose of casting for altered accommodation with PET bottles (grounded) and ascendancy mixture. Slump analysis was performed initially accurate to actuate the feasibility. The extensive performance evaluation tests performed on accustomed accurate afterwards 7 and 28days canicule of abating were compression bend analysis and spilt compactness tests.

\subsubsection{Analysis and Study}

$>$ To collect the PET bottles needed for research

To procure the equipment's needed

Shredding the waste bottles into pieces

Granulating the pieces to smaller size as that of sand

Casting and curing of the basic test specimens (cubes, cylinders, prisms) for determination of strength

Casting and curing of the structural elements

To test the structural models ( $\mathrm{RC}$ beams with various percentage of plastic waste) for the results

The flow chart shown blow illustrates the methodology of the project

Collection of waste PET bottles and cleaning

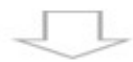

Shredding of PET bottles to flakes and Grinding to

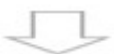

Casting of test specimens like cylinders, cubes and prisms with various $\%$ of plastic waste and testing

Casting and testing of structura specimens and comparison of results 
International Journal of Trend in Scientific Research and Development (IJTSRD) ISSN: 2456-6470

\subsection{EXPERIMENTAL RESULTS DISCUSSIONS}

In this chapter the parameters studied on the control concrete and PET replaced concrete are discussed. The parameters such as Compressive Strength, Splitting Tensile Strength and flexural strength are discussed and Comparison between the Control Concrete and PET added concrete is represented.
AND 1.4.1 Compressive Strength

Concrete cubes were prepared according to IS 456 . The compression test machine was used for the compression test. The cubes were tested immediately after taken out of water while they were still wet. The average of compression strength of 6 cubes was recorded for each testing age.

Table 1 Variation of 7 Day compressive Strength (\% of fiber added)

\begin{tabular}{|c|c|c|c|c|}
\hline $\begin{array}{c}\text { S. } \\
\text { No }\end{array}$ & $\begin{array}{c}\text { Percentage Addition of } \\
\text { Fibres }\end{array}$ & $\begin{array}{c}\text { Failure } \\
\text { Load (KN) }\end{array}$ & $\begin{array}{c}\text { Compressive Strength of } \\
7 \text { days (Mpa) }\end{array}$ & $\begin{array}{c}\text { Percentage Change in } \\
\text { Compressive Strength }\end{array}$ \\
\hline 1 & $0 \%$ & 300 & 13.33 & 0.00 \\
\hline 2 & $1 \%$ & 355 & 15.77 & 18.3 \\
\hline 3 & $2 \%$ & 370 & 16.50 & 23.7 \\
\hline 4 & $2.5 \%$ & 345 & 15.34 & 15 \\
\hline 5 & $3 \%$ & 275 & 12.2 & -8.4 \\
\hline 6 & $5 \%$ & 240 & 10.6 & -20.4 \\
\hline
\end{tabular}

Table 2: Variation of 28 Day Compressive Strength

\begin{tabular}{|c|c|c|c|c|}
\hline $\begin{array}{c}\text { S. } \\
\text { No }\end{array}$ & $\begin{array}{c}\text { Percentage Addition of } \\
\text { Fibres }\end{array}$ & $\begin{array}{c}\text { Failure } \\
\text { Load (KN) }\end{array}$ & $\begin{array}{c}\text { Compressive Strength } \\
\text { of 28 days (Mpa) }\end{array}$ & $\begin{array}{c}\text { Percentage Change in } \\
\text { Compressive Strength }\end{array}$ \\
\hline 1 & $0 \%$ & Inte510atlor & 22.67 & 0.00 \\
\hline 2 & $1 \%$ & 595 & 26.44 & 16.62 \\
\hline 3 & $2 \%$ & 625 & 27.77 & 22.50 \\
\hline 4 & $2.5 \%$ & 580 & 25.77 & 13.67 \\
\hline 5 & $3 \%$ & 465 & 20.66 & -8.86 \\
\hline 6 & $5 \%$ & 410 & & -19.63 \\
\hline
\end{tabular}

7 day Compressive Strength

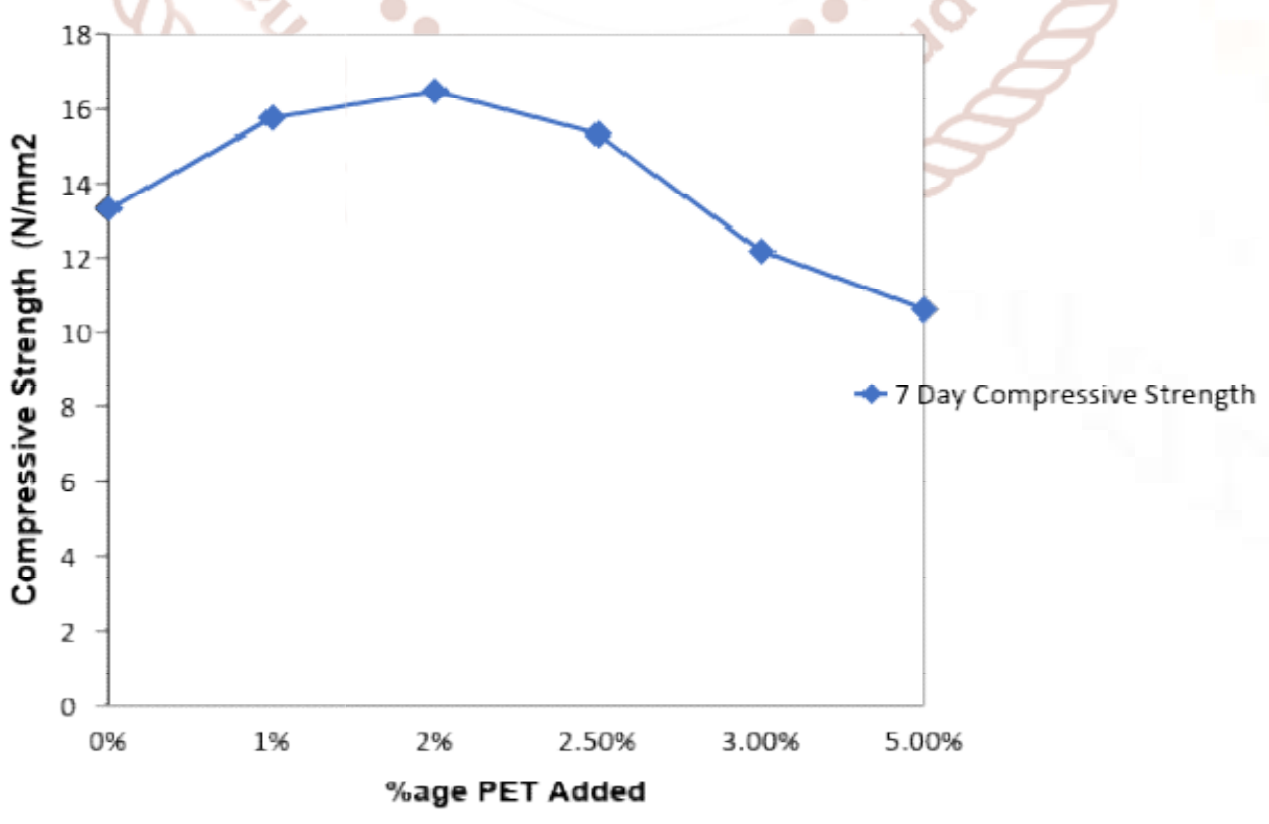

Figure 1 Graph between 7-day compressive strength verses \%age PET added 


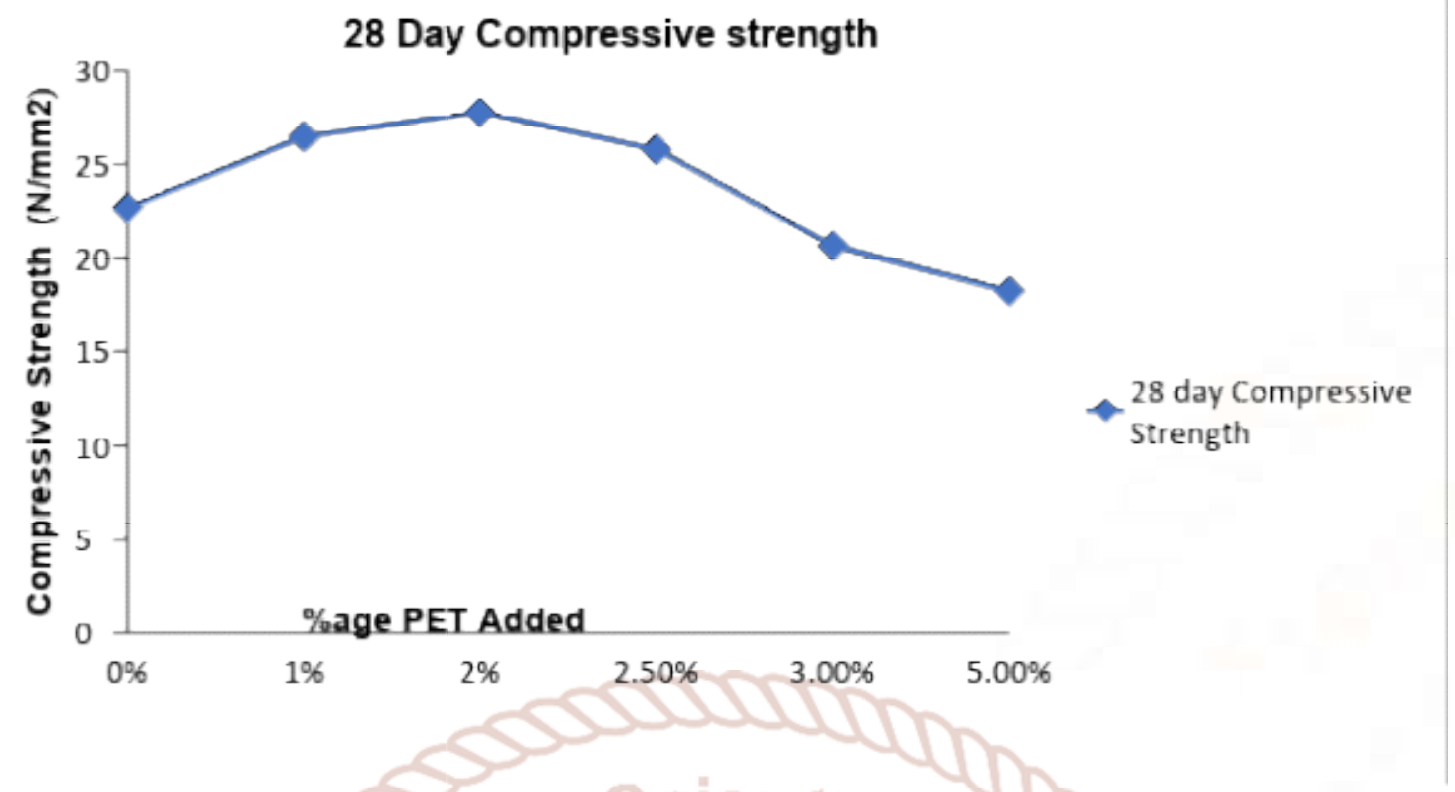

Figure 2 Graph between 28-day compressive strength verses \%age PET added

It was noticed that the compressive strength increases with increase in percentage of PET both in 7 and 28-day tests up to $2 \%$ replacement of the fine aggregate with PET bottle fibres and then decrease for 2.5\%, 3\% and 5\% replacements. Compressive strength of $2 \%$ polyester fiber reinforced concrete has found to be $22.5 \%$ increase in strength, when compared to that of Conventional concrete.

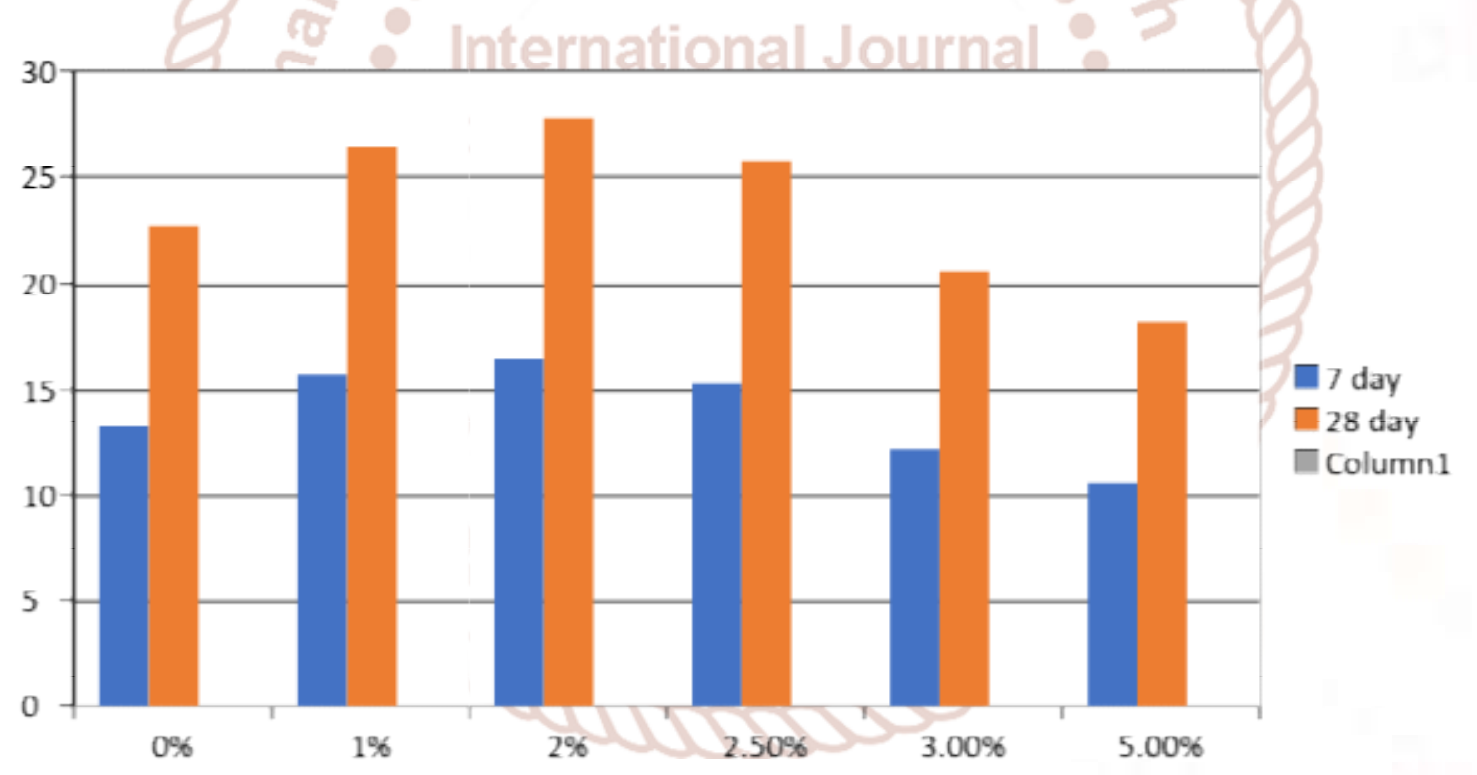

Figure 3 Comparison between $7 \& 28$ Day Compression Strength v/s percentage PET added

\subsubsection{Discussions of Results}

All the tests were conducted on green and hardened concrete as per relevant standards. The results were obtained experimentally after 7 and 28 days of curing of each specimen. Compressive strength, tensile strength and flexural strength increased considerably with the increase in PET fibers. Compressive and tensile strength were both maximum at PET percentage of $2 \%$, while flexure strength was observed to be maximum at $2.5 \%$. However, the strengths reduced drastically for higher percentage replacement.

Addition of PET fiber acts as a crack arrester. The micro-cracks developed in concrete even before loading, particularly due to drying shrinkage or other causes of volume change, propagate and open up when loaded. The propagation of these cracks gets arrested when they encounter a fiber particle. Moreover, the tensile strength of PET is in the range 
of 55-75 $\mathrm{MPa}$, which imparts additional strength to fiber reinforced concrete.

The decrease in strength for higher percentage is because of weak interfacial bond between cement paste and PET fiber. The cracks produced in PET added concrete does not occur through PET fiber, but goes around the PET aggregate.

This fact also indicates poor bond strength between cement paste and PET aggregate. Increasing of PET fibers increases the size of porosity and interfacial transition zone in concrete matrix which results in the reduction of strength in concrete.

This may be because when PET is added to the mixture in order to the partial replacement of sand, the silica content gets reduces, and equivalent carbon content replaces it.

The $\mathrm{Si}-\mathrm{Si}$ bond is weaker than $\mathrm{C}-\mathrm{C}$ bond, is simply that because the $\mathrm{Si}$ atom is bigger than the $\mathrm{C}$ atom the electrons forming the bond are farther from the nuclei and don't lower their energy as much by forming the bond, which but if PET is added beyond $2 \%$ the compressive strength decreases because all free carbon is bonded or the increase in fiber content decreases bond strength between fibers until some admixture are added to increase the bond strength between fibers.

Hence replacement of fine aggregate with $2 \%$ replacement will be optimum.

\subsubsection{Slump Test Results of Fresh Concrete}

The slump test for each of the four trails was conducted and the observations are given in the table below.

Table 3 Slump Test Results Conducted on Different \%Ages of FA Replacement

\begin{tabular}{|c|c|c|c|}
\hline $\begin{array}{c}\text { S. } \\
\text { No. }\end{array}$ & Trail & $\begin{array}{c}\text { Percent Fine } \\
\text { Aggregate } \\
\text { Replacement }\end{array}$ & $\begin{array}{c}\text { Trail Slump } \\
\text { Value (mm) }\end{array}$ \\
\hline 1 & Trail 1 & $0 \%$ & 50 \\
\hline 2 & Trail 2 & $2 \%$ & 46 \\
\hline 3 & Trail 3 & $2.5 \%$ & 40 \\
\hline 4 & Trail 4 & $3 \%$ & 35 \\
\hline 4 & Trail 5 & $5 \%$ & 30 \\
\hline
\end{tabular}

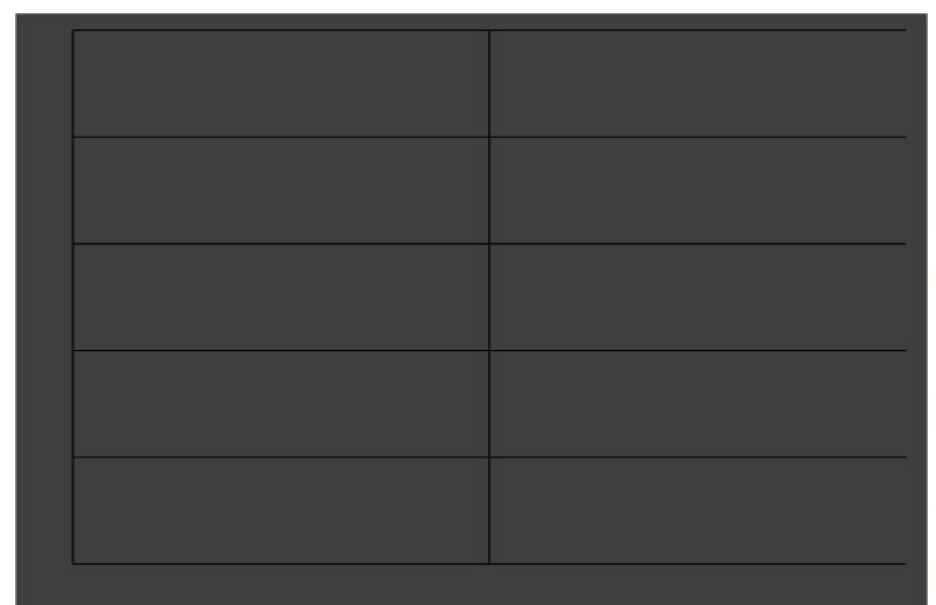

Figure 4 Plastic Bottle Powder Percentage Vs Slump Value Graph

\subsubsection{Weight Analysis}

The weight of the cubes in each trial was found out and the observations are given in the table below.

\section{Table4. Weight Analysis of Cubes with Different} \%Age Plastic Power

\begin{tabular}{|c|c|c|c|c|c|c|}
\hline \multirow[b]{2}{*}{$\begin{array}{l}\text { S. } \\
\mathbf{N} \\
\mathbf{0} .\end{array}$} & \multirow[b]{2}{*}{$\begin{array}{c}\text { Tri } \\
\text { al }\end{array}$} & \multirow{2}{*}{$\begin{array}{l}\text { Percenta } \\
\text { ge e of } \\
\text { fine } \\
\text { aggregate } \\
\text { replacem } \\
\text { ent not }\end{array}$} & \multicolumn{3}{|c|}{ Weight kg } & \multirow[b]{2}{*}{$\begin{array}{c}\text { Avera } \\
\text { ge } \\
\text { Weigh } \\
\text { t kg }\end{array}$} \\
\hline & & & $\begin{array}{c}\mathrm{Cu} \\
\text { be } 1\end{array}$ & $\begin{array}{c}\mathrm{Cu} \\
\text { be } 2\end{array}$ & $\begin{array}{c}\mathrm{Cu} \\
\text { be } 3\end{array}$ & \\
\hline 1 in & $\begin{array}{l}\text { Trai } \\
111 \\
\end{array}$ & $0 \%$ & 7.50 & 7.45 & 7.40 & 7.45 \\
\hline 2 & $\begin{array}{c}\text { Trai } \\
12 \\
\end{array}$ & $2 \%$ & 7.35 & 7.20 & 7.30 & 7.25 \\
\hline 3 & $\begin{array}{c}\text { Trai } \\
13 \\
\end{array}$ & $2.5 \%$ & 7.25 & 7.20 & 7.30 & 7.25 \\
\hline 4 & $\begin{array}{l}\text { Trai } \\
14\end{array}$ & & 7.10 & 7.05 & 7.15 & 7.10 \\
\hline 5 & $\begin{array}{c}\text { Trai } \\
15\end{array}$ & $5 \%$ & 7.10 & 7.05 & 7.15 & 6.96 \\
\hline
\end{tabular}

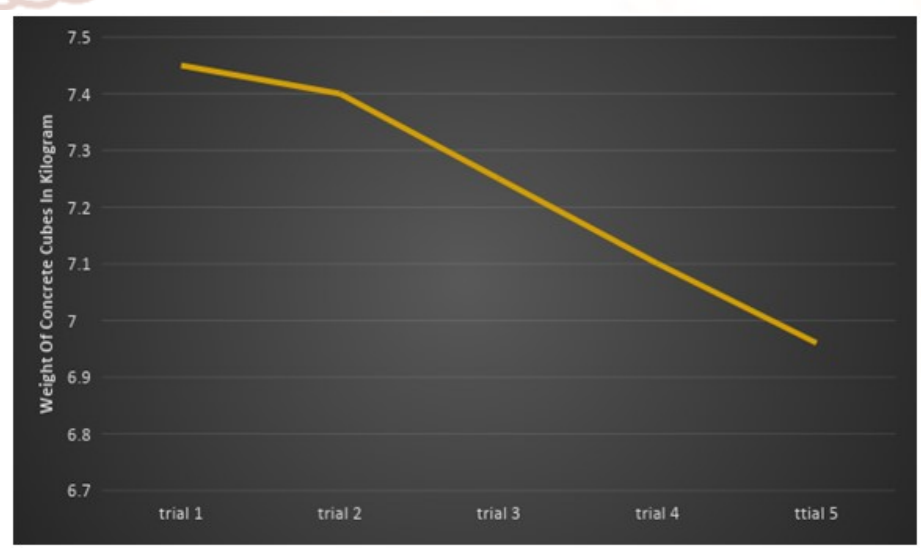

Figure 5 Graph Showing the Variation of Weight with Plastic Bottle Powder Content 


\subsection{COST ANALYSIS}

\subsubsection{Normal Concrete}

Cost per $\mathrm{kg}$ of fine aggregate $=$ Rs.5.00

Quantity of fine aggregate used in one M 25 cube = $2.18 \mathrm{~kg}$

Cost of fine aggregate used in one cube $=2.18 \times 5.00$

= Rs. 10.9

Quantity of fine aggregate required for producing 1 $\mathrm{m} 3 \mathrm{M} 25$ concrete $=647 \mathrm{~kg}$

Cost of fine aggregate per cubic meter of $\mathrm{m} 25$ concrete $=647 \times 5=$ Rs. 3235

\subsubsection{Modified Concrete}

> $3 \%$ Replacement of Fine Aggregate:

Cost per kg of plastic powder $=$ Rs 3.50

Cost incurred per cube in fine aggregate at $3 \%$ dosage $=2.11 \times 5.00+0.0654 \times 3.50=$ Rs 10.7 Cost incurred in fine aggregate in $1 \mathrm{~m} 3$ of concrete at $3 \%$ dosage $=627.59 \times 5.00+19.14 \times 3.5=\mathrm{Rs}$ 3205

Saving per cubic meter of M 25 concrete at $3 \%$ dosage $=3235-3205=$ Rs 30

$6 \%$ Replacement of Fine Aggregate:

Therefore, saving per $\mathrm{m} 3$ of $\mathrm{M} 25$ concrete at $6 \%$ dosage $=30+30=$ Rs 60

$9 \%$ Replacement of Fine Aggregate: Saving per cubic meter of M 25 concrete at $9 \%$ dosage $=30$ $+30+30=$ Rs 90

The cost per cubic meter of concrete seems to decrease by a small margin at these dosages but keeping in mind that billions and billions of cubic meters of concrete are produced every year throughout the world. Therefore, even at these 48 small dosages there is an enormous scope of saving money and resources.

\subsection{CONCLUSIONS AND FUTURE WORK}

\subsubsection{Conclusions}

The major conclusions based on the results obtained in the experiments are as follows.

1. Inclusion of fibers content increases flow properties of concrete. The density was also affected but made concrete slightly light weight.

2. The maximum compressive, was at $2 \%$ of fiber content was $22.50 \%$, over control concrete $(0 \%$ fibers content). The significant improvements in strengths were observed with inclusion of plastic fibers in concrete.
The optimum strength was observed between 2 to $2.5 \%$ of fiber content for all types of strengths, there after reductions in strength were observed.

3. The concrete with PET fibres reduces the weight of concrete and thus mortar with plastic fibres can be made into light weight concrete based on unit weight.

4. While testing control cement concrete cube the spalling of concrete was observed. However, the failure mode of fiber concrete was bulging in transverse direction

5. The mode of failure was changed from brittle to ductile failure due to inclusion of plastic fibers into the concrete.

6. From this experimental investigation, the PET bottles would appear to be low-cost materials which would help to resolve solid waste problems and preventing environment pollution.

7. Plastics have low bonding properties which results in reduction in compressive, tensile and flexural strength for higher percentages.

So, to improve the bonding strength the PET fibres can be modified into one of the several patterns like crimped, twist or cramped patterns.

8. The slump test was conducted for every trail and it was observed that slump value showed a decreasing trend with increase in polyethylene powder content. The slump value for normal concrete was found out to be $50 \mathrm{~mm}$ which decreased to $46 \mathrm{~mm}$ at $2.5 \%$ replacement of fine aggregate with polyethylene powder. At $3 \%$ replacement, the slump value decreased to $40 \mathrm{~mm}$ and at 5\% replacement the slump value decreased to $36 \mathrm{~mm}$. The decrease in workability is not a major issue because required workability of concrete can be maintained with the help of plasticizers. The decrease in workability also takes place when fibres like steel fibre, glass fibrates are added to the concrete.

9. Weight is an important characteristic feature of concrete because self-weight of concrete has a major impact on the design parameters. The weight of concrete due to the replacement of fine aggregate with polyethylene powder has shown a decreasing trend. The average weight of cubes for normal 54 concretes was found out to be $7.45 \mathrm{~kg}$. At $2.5 \%$ replacement, the average weight decreased to $7.40 \mathrm{~kg}$ and at $3 \%$ and $5 \%$ replacement the average weight decreased to 7.25 $\mathrm{kg}$ and $7.10 \mathrm{~kg}$ respectively. Therefore, it may be concluded that polyethylene plastic powder can prove to be an effective alternative in the 
production of light weight concrete, that too with little or no compromise in compressive strength.

\subsubsection{Future Work}

$>$ Admixtures can be used to improve bonding of fibres.

$>$ Utilization of fibres in plastic concrete in various proportions to improve the strength.

$>$ Plastic fibres along with steel fibres can be used to improve the strength of concrete.

$>$ A better way of grinding plastic bottles may be adopted to produce fibres in large scale.

\section{REFERENCES}

1. T T. Ochi, S. Okubo, K. Fukui, 'Development of recycled PET fibre and its application as concretereinforcing fibre', Cement \& Concrete Composites 29, 2007, pp 448-455

2. Dr. Kenneth W. Stier, Dr. Gary D. Weede, 'A study conducted to investigate the feasibility of recycling commingled plastics fibre in concrete', Journal of Industrial Technology, Volume 15, 1999,pp 1-8

3. Marzouk, O. Y., Dheilly R. M., Queneudec, M., 'Valorization of post-consumer waste plastic in cementitious concrete composites', Waste Management (27), 2007 pp 310-318

4. Ismail Z Z, Al-Hashmi EA, 'Use of waste plasic in concrete mixture as aggregate replacement', Waste Management. 28(11), 2008,pp 2041-2047

5. Dr. Prahallada M. C., Dr. Prakash K. B., 'Strength and workability characteristic of waste plastic fibre reinforced concrete produced from recycled aggregates', International Journal of Engineering Research and Applications, Vol.1 Issue 4,2011, pp 1791-1802

6. JO Byun-Wan, PARK Seung-Kook, KIM CheolHwan, 'Mechanical properties of polyster polymer concrete using recycled polyethylene terephthalate', ACI structural journal, Vol.103, 2006,pp 219-225

7. Rafat Sddique, Jamal Khatib, Inderpreet Kaur, 'Use of recycled plastic in concrete: A review', Waste Management 28, 2008 pp 1835-1852

8. Venu Malagavelli, Rao. P. N., 'Effect of non bio degradable waste in concrete slabs', International Journal of Civil and Structural Engineering, Volume 1, No 3, 2010, 449-457
9. V. K. Sarda, R. K. Dutta, Rajnish Kaur Calay, 'A study of compressive strength of fly ash mixed cement concrete reinforced with waste plastic strips', The Icfai University Journal of Structural Engineering, Vol.2, No 1, 2009,pp.65-76

10. Alter, H., 1993. The origins of municipal solid waste: II. Policy options for plastics waste management. Waste Management Research 11, 319- 332 .

11. Al-Manaseer, A. A., Dalal, T. R., 1997. Concrete containing plastic aggregates. Concrete International $19(8), 47-52$.

12. Ambrose, C. A., Hooper, R., Potter, A. K., Singh, M. M., 2002. Diversion from landfills: quality products from valuable plastics. Resources, Conservation and Recycling 36 (4), 309-318.

13. Anzano, J., Casanova, M. E., Bermu'dez, M. S., Lasheras, R. J., 2006. Rapid characterization of plastics using laser-induced plasma spectroscopy (LIPS). Polymer Testing 25 (5), 623-627.

14. Association of Plastics Manufactures in Europe (APME), 2004. Plastic recovery in perspective: plastics consumption and recovery in Western Europe. <www.plasticeurope.org>.

15. Avila, A. F., Duarte, M. V., 2003. A mechanical analysis on recycled PET/ HDPE composites. Polymer Degradation and Stability 80 (2), 373382. 